\title{
Evaluating the exchange rate and commodity price nexus in Malaysia: evidence from the threshold cointegration approach
}

\author{
Shamaila Butt, Suresh Ramakrishnan, Nanthakumar Loganathan ${ }^{*}$ and Muhammad Ali Chohan
}

* Correspondence: n4nantha@ yahoo.com

Azman Hashim International Business School, Universiti Teknologi Malaysia, 81310 Johor Bahru, Johor, Malaysia

\begin{abstract}
This paper examines the long- and short-run dynamics of asymmetric adjustment between the nominal exchange rate and commodity prices, namely oil, palm oil, rubber, and natural gas prices, in Malaysia using monthly data from January 1994 to December 2017. The relationship between exchange rate and each commodity price is examined in terms of Engle-Granger and threshold cointegrations. The estimated results provide evidence of long-run threshold cointegration and show that the adjustments towards the long-run equilibrium position are asymmetric in the short run. Furthermore, this study finds evidence of a unidirectional causal relationship running from the nominal exchange rate to oil price in the long and short run using a spectral frequency domain causality application. There is also empirical evidence of bidirectional causality between the nominal exchange rate and palm oil price, rubber price, and natural gas price in the long and short run. Overall, the findings have significant implications for the current debate on the future of primary commodities in Malaysia.
\end{abstract}

Keywords: Commodity prices, Exchange rate, Threshold cointegration

\section{Introduction}

The exchange rate is at the center of the policy debate in both developed and emerging economies. The literature has considered a wide variety of fundamentals as the key determinants of the exchange rate. The earliest and most prominent factors for exchange rate determination are the monetary fundamentals. Meese and Rogoff (1983) highlighted that monetary fundamentals contain limited information over the short to the medium term. Since then, the empirical evidence of the influence of monetary fundamentals on the exchange rate has been mixed, with the general conclusion that the nominal exchange rate dynamics can be explained by monetary fundamentals over long horizons (Khan et al. 2019; Xie and Chen 2019; Tawadros 2017). Besides monetary fundamentals, commodity prices, including energy and agricultural commodity prices, are considered an important determinant for export-oriented economies.

(c) The Author(s). 2020 Open Access This article is licensed under a Creative Commons Attribution 4.0 International License, which permits use, sharing, adaptation, distribution and reproduction in any medium or format, as long as you give appropriate credit to the original author(s) and the source, provide a link to the Creative Commons licence, and indicate if changes were made. The images or other third party material in this article are included in the article's Creative Commons licence, unless indicated otherwise in a credit line to the material. If material is not included in the article's Creative Commons licence and your intended use is not permitted by statutory regulation or exceeds the permitted use, you will need to obtain permission directly from the copyright holder. To view a copy of this licence, visit http://creativecommons.org/licenses/by/4.0/. 
Several studies investigated countries with different exchange rate regimes and economic structures, with the countries with commodity currencies having been paid more attention (Ferraro et al. 2015; Rossi 2013; Chen and Rogoff 2003).

Oil is an important energy commodity, with many uses, including as a source of energy, raw material in industries, and trading commodity. Further, oil is considered a key player in explaining the dynamics of agricultural commodity prices. The theoretical analysis of this relationship considers two transmission channels from nominal oil prices to the nominal exchange rates, namely the portfolio and wealth effect channels (Habib et al. 2016). The portfolio channel considers the medium to the long run, while the wealth channel confirms the short-run effects of oil prices on the nominal exchange rate. These two-transmission channels were initially proposed by Krugman (1983) and Golub (1983), respectively. The basic concept is that wealth is transferred to oilexporting countries, which improves exports and trade deficits, resulting in stabilizing the domestic currency (Beckmann and Czudaj 2017). However, the nominal causality from exchange rates to oil prices (denominated in US dollars) follows the expectation channel. The expectation channel explains that a rise in the US dollar increases oil prices in the domestic currency, which decreases demand for oil outside the US, thus leading to fall in oil price (Habib et al. 2016).

Although oil price affects commodity production through input prices, it also potentially affects agricultural products through competition in output markets or biofuels. A direct linkage between oil price and agriculture products exists, while the indirect effect is obvious through the exchange rate (Nazlioglu and Soytas 2012). Chenery (1975) discussed the disruption in world trade due to the rise in oil and agriculture prices. He explained that substantial adjustments are necessary after prices rise due to changes in productivity. Moreover, oil and natural gas prices are cointegrated because these fuels can be substituted (Hartley and Medlock III 2014). There is also evidence that technological changes alter the substitutability between natural gas and oil products, which in turn impacts the nominal exchange rate. As a result, this phenomenon increases the researchers' interest for investigating the impact of the change in energy and agriculture commodity prices on the nominal exchange rate.

Different techniques can be applied to capture the impact of energy and agriculture commodity prices on the nominal exchange rate behavior in the long and short run. As traditional linear techniques may be mis-specified, they are hence unable to adequately capture the complex nonlinear characteristics of exchange rate dynamics (Alom 2016; Khashei et al. 2009). The issue of non-linear patterns in exchange rate determination induces the researcher to use nonlinear techniques. The theoretical and empirical roots of nonlinear behavior are caused by economic crises such as the OPEC decision, 1997-1998 Asian financial crisis, 2008-2010 global financial crisis, and the geopolitical extreme events of 2006 that lead to an oil shock (Alom 2016). All these factors may generate structural breaks and asymmetric responses in the behavior of exchange rates and distort linearity. Past studies have provided considerable evidence in favor of nonlinear exchange rate dynamics (Hansen 2011; Teräsvirta et al. 2010; Bahmani-Oskooee et al. 2008). However, these empirical evidences use nonlinear symmetry-imposing models. Symmetric adjustment models are unable to capture asymmetric policy preferences. Under these circumstances, there is a need to account for these effects by estimating a 
nonlinear adjustment model that allows considering the speed of adjustment to equilibrium of the nominal exchange rate.

The emerging economy of Malaysia has recently experienced unprecedented declines in economic performance due to the recent depreciation of the ringgit (MYR) and declining effect of oil prices. Further, the Malaysian economy was severely influenced by the Asian financial and global financial crises, which directly affected its exchange rate dynamics. Additionally, the different Malaysian exchange rate regimes make it more complex compared to the other emerging economies (Lye et al. 2011). Furthermore, the role of commodity prices cannot be ignored in Malaysia, which has an exportoriented and open economy that depends on the export of commodities. It is also the second largest palm oil producer after Indonesia. The Malaysian economy currently accounts for $44 \%$ of world exports and $39 \%$ of the global production of palm oil. It exports $27 \%$ of the global production of oil and $12 \%$ of that of fat (MPOB 2019). This industry is thus considered the fourth largest contributor to Malaysia's economy, accounting for MYR 52.7 billion of gross national income in 2011 and an increase to MYR 178 billion is estimated by 2020. The total export value of the palm oil industry in Malaysia was MYR 60.17 billion in 2015 (DOSM 2018). As Malaysia is a palm oil producer and the largest exporter, an increase in palm oil price would be in favor of the trade balance and currency appreciation.

Besides palm oil, Malaysia is also a net exporter of gas. Based on the latest world liquefied natural gas (LNG) report, Malaysia (10.2\%) is the third biggest exporter of LNG after Qatar (31.8\%) and Australia (12\%) (EIA 2016; IGU 2016). Furthermore, Malaysia Investment Development Authority (MIDA) identified that the Malaysian oil and gas industry will become prominent in the future because the oil and gas contribute $20 \%$ to the Malaysian GDP at the moment. Additionally, the rubber industry is the fourth largest export-driven commodity in Malaysia. According to Rubber Statistics Malaysia, the natural rubber production in June 2018 rose by $16.3 \%$ to 41,578 tones compared to that of May 2018 of 35,761 tones. For year-on-year, the production decreased by $17.9 \%$.

Figure 1 shows the negative impact of oil price on the exchange rate. This tendency confirms crude oil has a prominent impact on the Malaysian exchange rate. Palm oil price is also found to have a negative relationship with the nominal exchange rate, as shown in Fig. 2. The relationship between the nominal exchange rate and palm oil price is presenting a similar tendency from 1998 to 2015. Figures 3 and 4 show similar effects, that is, a negative relationship between the nominal exchange rate, rubber price,

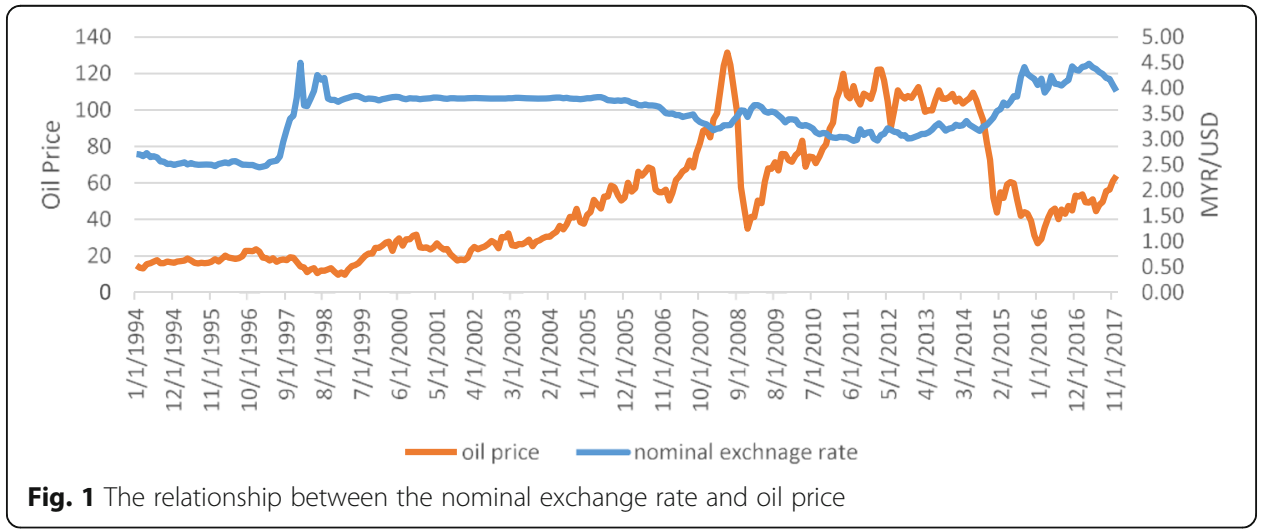




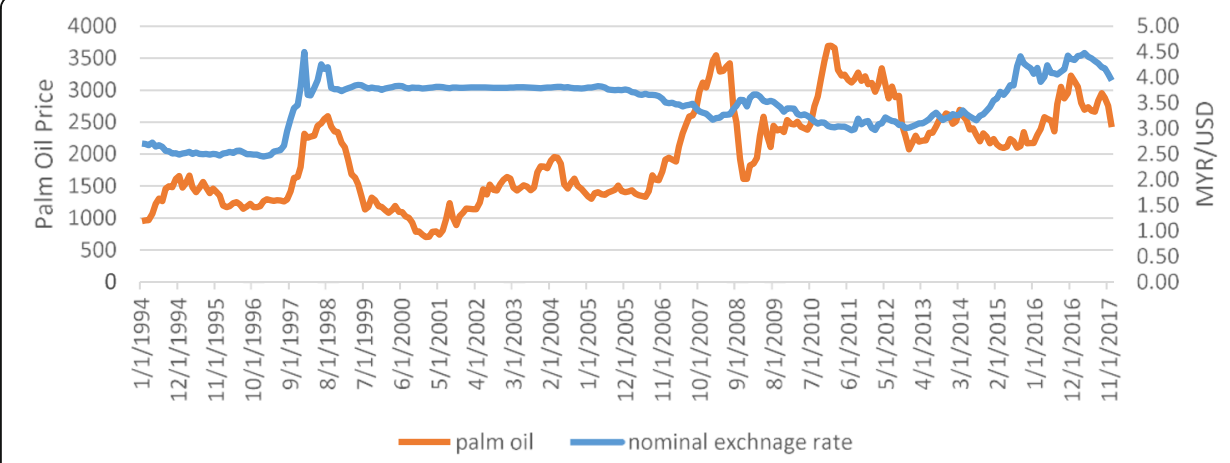

Fig. 2 The relationship between the nominal exchange rate and palm oil price

and natural gas price. The historical data show a strong negative nexus between commodity prices and nominal exchange rate. This association is important for Malaysia as a net exporter of commodities and the volatility may have a significant impact on the determination of the Malaysian exchange rate.

In determining the exchange rate, commodity prices are considered as an important predictor (Rossi 2013). Chen and Rogoff (2003) emphasized that commodity prices are a dominant new monetary model for exchange rate determination. They identified a commodity price change to be an essential external shock for small and emerging economies. Export-led emerging economies experience the appreciation of the exchange rate in parallel with an upsurge in the export price of commodities. Additionally, Chen (2004) found that the movements in the commodity prices of three exporters, Australia, Canada, and New Zealand, exhibit a robust response to the nominal exchange rate. Chen and Rogoff's (2003) results were confirmed by Ferraro et al. (2015), who examined the impact of in-sample commodity prices on the exchange rate.

More recently, Zou et al. (2017) investigated the dynamic long-run relationship between the exchange rate and commodity prices. They found that country-specific commodity price indices increased the value of the currency in Australia and New Zealand. Conversely, Chen et al. (2010) argued that commodity prices do not predict the exchange rate by considering the weighted average index of total commodities instead of individual commodities. Golub (1983) and Krugman (1983) inferred that an increase in price of oil generates surplus for oil exporting economies and deficits for oil importing

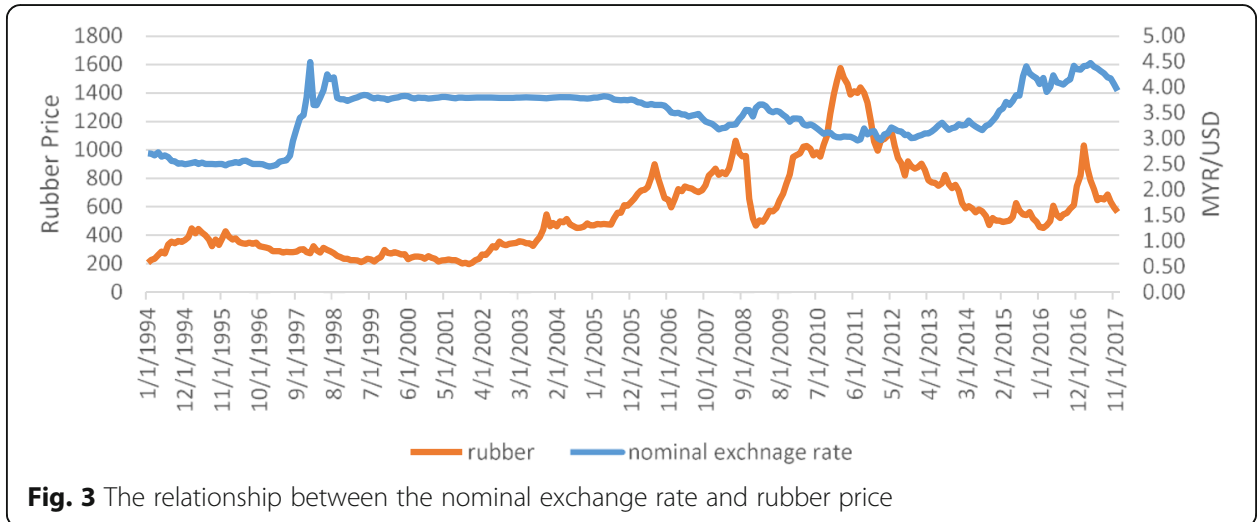




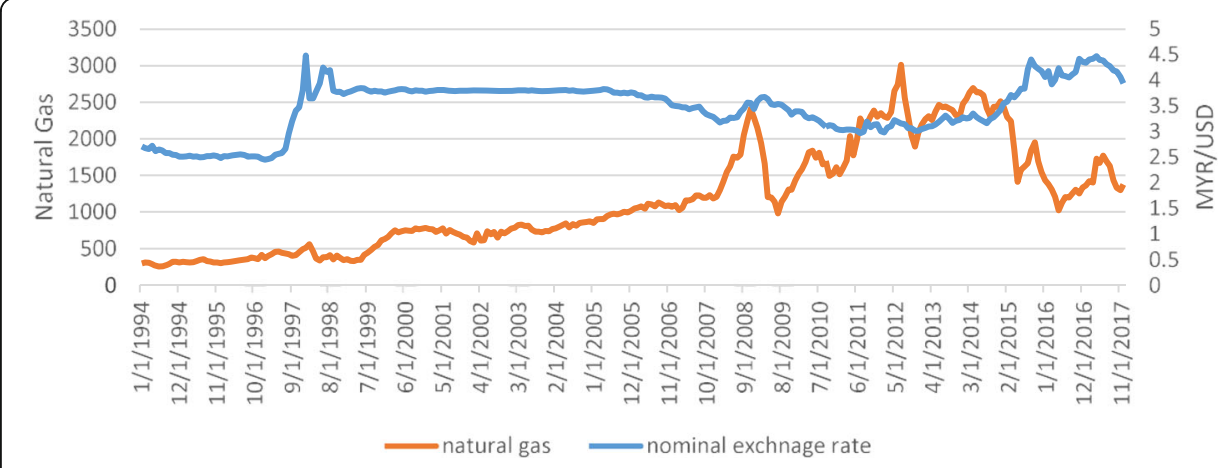

Fig. 4 The relationship between the nominal exchange rate and natural gas price

economies through the unequal distribution of wealth, which eventually affects the exchange rate. For oil exporting countries, extant studies generally provided evidence of a negative relationship between exchange rate and oil price, which leads to currency appreciation (Aziz et al. 2013).

Basher et al. (2016) employed a Markov switching approach to determine that the change in oil price leads to an exchange rate appreciation in oil-exporting economies. Hussain et al. (2017) showed that 12 Asian countries (except Hong Kong and Japan) had weak negative cross-correlation between oil price and the exchange rate from 2006 to 2016. By contrast, Yousefi and Wirjanto (2004) determined that oil price has a positive impact on the US Dollar in five OPEC countries. For India, Ghosh (2011) investigated that an increase in oil prices may have appreciates the Indian exchange rate relative to the US one at a daily frequency from 2007 to 2008. Similarly, Reboredo et al. (2014) argued that oil price has a significant positive impact on the exchange rate using cross-correlation. Tiwari and Albulescu (2016) agreed that a significant positive relationship exists in India between oil price and the exchange rate from January 1980 to February 2016 in the short run. While in for China, Chao et al. (2019) has used some recent monitoring method to improve the efficiency of the financial market.

Other studies also found strong links between the exchange rate and oil price in the long run. For example, Benhmad (2012) examined the long run causality between oil price and the exchange rate using wavelet analysis. Further, Beckmann and Czudaj (2017) stressed the strong association between the exchange rate and oil price in the long and short run. Furthermore, palm oil provides is a contributing factor for the exchange rate behavior (Aprina 2014). Oladipo and Akinbobola (2011) found that an increase in the price of palm oil may affects its export value, which in turn leads to strengthening the currency. Although past studies focused on global or country-specific commodity price indexes, this paper mainly focuses on the response of the exchange rate predicted by Malaysia's fuel and agriculture commodity impact on the nominal exchange rate. As such, it examines the upward and downward adjustment of the shortrun deviation of oil, palm oil, rubber, and natural gas prices on the nominal exchange rate in the long-run in Malaysia. The direction and intensity of the relationship are considered through causality. The rest of the paper is organized as follows. Section 2 describes the empirical estimation strategies. Section 3 reports the results and discussion, and Section 4 concludes the paper. 


\section{Empirical estimation strategies}

This study uses the bilateral nominal exchange rate to capture the dynamics of the MYR/USD exchange rate. The data are collected from the Department of Statistics (DOSM 2018), Central Bank of Malaysia (BNM 2018), and the Organization of the Petroleum Exporting Countries (OPEC 2018). The data consist of monthly observations from January 1994 to December 2017. The monthly observations are calculated from the daily averages. The description of the data is found in Table 1. The nominal oil price is obtained from the OPEC dataset and measured in US dollars per barrel. The rubber price is approximated by the general rubber (free on board, Sen./kg) and crude palm oil price (per ton) is used as the palm oil price. Additionally, the export unit value of LNG is used as a proxy for the natural gas price. All variables are seasonally adjusted and transformed into natural logarithms.

Further, the structural unit root test and Engle-Granger cointegration analysis are used to obtain further insights into the observed co-movement of the nominal exchange rate, oil price, palm oil price, rubber price, and natural gas price. The Zivot and Andrews (2002) and Perron (1989) tests are used to determine the stationarity of the variables as per Eq. (1):

$$
\Delta \mu_{t}=\rho \mu_{t-1}+\sum_{i=1}^{k} \lambda_{i} \Delta \mu_{t-i}+v_{t}
$$

Furthermore, due to the nonlinear behavior of the exchange rate, the BDS test was applied to detect chaotic dynamics. The identical distribution (iid) in the null hypothesis can detect non-random chaotic behavior in the data series. The BDS test statistic is expressed as follows:

$$
V_{m, \varepsilon}=\sqrt{T} \frac{C_{m, \varepsilon}-C_{1, \varepsilon}^{m}}{s_{m, \varepsilon}}
$$

Where, $s_{m, \varepsilon}$ represents the standard deviation of the expression $\sqrt{T}\left(C_{m, \varepsilon}-C_{1, \varepsilon}^{m}\right)$, as per LeBaron (1997). The BDS statistic in distribution $N(0,1)$ is explained as follows:

$$
V_{m, \varepsilon} \stackrel{d}{\rightarrow} N(0,1)
$$

Therefore, the independent and identical distribution hypothesis is rejected at the 5\% significance level when $\left|V_{m, \varepsilon}\right|>1.96$. Moreover, Engle and Granger's (1987) long-run cointegration relation test is employed to confirm the stable, linear, and

\begin{tabular}{|c|c|c|}
\hline Variable name & Description & Data Source \\
\hline Nominal exchange rate (NER) & $\begin{array}{l}\text { Nominal Malaysian Ringgit, } \\
\text { per US dollar (average) }\end{array}$ & Central Bank of Malaysia \\
\hline Oil price (OP) & OPEC basket price per barrel & $\begin{array}{l}\text { Organization of the Petroleum } \\
\text { Exporting Countries (OPEC) }\end{array}$ \\
\hline Palm oil price (PO) & Crude palm oil/Ton & Department of Statistics Malaysia (DOSM) \\
\hline Rubber price (RUB) & General rubber, FOB, Sen/kg & Malaysian Rubber Exchange \\
\hline Natural gas price (NG) & Liquefied natural gas Curn & Department of Statistics Malaysia (DOSM) \\
\hline
\end{tabular}
long-run relationship between energy, agriculture commodity prices, and the

Table 1 Data description and data sources 
nominal exchange rate. The assumption of linearity in the adjustment to the longrun equilibrium is symmetric in nature. Further, it also assumes that an increase or decrease in the deviation from the long-run equilibrium relationship are corrected in the same way. The long-run relationship between nominal exchange rate and commodity prices is as follows:

$$
\begin{aligned}
& N E R_{t}=\beta_{0}+\beta_{1} O P_{t}+\mu_{t}, \\
& N E R_{t}=\beta_{0}+\beta_{1} P O_{t}+\mu_{t}, \\
& N E R_{t}=\beta_{0}+\beta_{1} R U B_{t}+\mu_{t}, \\
& N E R_{t}=\beta_{0}+\beta_{1} N G_{t}+\mu_{t},
\end{aligned}
$$

where $N E R_{t}$ denotes the nominal exchange rate, $O P_{t}$ oil price, $P O_{t}$ palm oil price, $R U B_{t}$ rubber price, $N G_{t}$ natural gas price, and $\mu_{t}$ the residual term.

The presence of nonlinearity in the variables and adjustment process cannot be determined by the linear cointegration technique. Therefore, Enders and Siklos' (2001) threshold cointegration is applied here, where the long-run cointegration is linear but the adjustment to long-run equilibrium level is also facing a nonlinear condition. The long-run cointegration and nonlinear adjustments are estimated by the threshold autoregressive (TAR) and momentum threshold autoregressive (M-TAR) models of threshold cointegration, as proposed by Enders and Siklos (2001). The residual from Eq. (8) is used for testing a model:

$$
\Delta \mu_{t}=\rho^{+} I_{t} \mu_{t-1}+\rho^{-}\left(1-I_{t}\right) \mu_{t-1}+\sum_{i=1}^{k} \lambda_{\mathrm{i}} \Delta \mu_{t-i}+v_{t},
$$

where $v_{t}$ iid $\left(0, \sigma^{2}\right)$ and $I_{t}$ represents the Heaviside indicator function:

$$
\mathrm{TAR}: I_{t}=\left\{\begin{array}{c}
1 \text { if } \mu_{t-1} \geq \tau \\
0 \text { if } \mu_{t-1}<\tau
\end{array}\right.
$$

Eq. (9) expresses the TAR model and Eq. (10) the M-TAR model, where $\tau$ is a threshold value endogenously suggested by Chan (1993). If $\mu_{t-1}$ and $\Delta \mu_{t-1}$ are above threshold $(\tau)$, the adjustment coefficient is $\rho^{+} \mu_{t-1}$. However, if $\mu_{t-1}$ and $\Delta \mu_{t-1}$ are below threshold $(\tau)$, the adjustment coefficient is $\rho^{-} \mu_{t-1}$. Enders and Siklos' (2001) threshold cointegration is considered as an alternative rule for M-TAR in setting the Heaviside indicator which is as follows:

$$
\text { M-TAR : } I_{t}=\left\{\begin{array}{c}
1 \text { if } \Delta \mu_{t-1} \geq \tau \\
0 \text { if } \Delta \mu_{t-1}<\tau
\end{array}\right.
$$

The threshold procedure comprises three stages. In the first stage, we estimate the TAR and MTAR models for the cointegration procedure. The null hypothesis $\left(\mathrm{H}_{0}: \rho^{+}=\right.$ $\rho^{-}=0$ ) of no cointegration is tested by comparing the critical values of the F-statistics with their corresponding actual values $(\Phi)$ as per Enders and Siklos (2001). If the null hypothesis of no cointegration is rejected, the long run cointegration between nominal exchange rate and commodity prices exists and we proceed to the second stage of the 
threshold cointegration. In the second stage, we estimate the symmetry of the null hypothesis $\left(\mathrm{H}_{0}: \rho^{+}=\rho^{-}\right)$. If the null hypothesis of symmetry is rejected $|\rho+| \neq|\rho-|$, it is an indication of nonlinear threshold cointegration between the nominal exchange rate and commodity prices. In the presence of a nonlinear threshold cointegration between the nominal exchange rate and each commodity's price, the final phase is the estimation of the threshold vector error correction model (TVECM) to adjust the short-run deviation in the long-run equilibrium. The TVECM expressions for oil, palm oil, rubber, and natural gas price are as follows:

$$
\begin{aligned}
& \triangle N E R_{t}=\alpha_{0}+\delta^{+} I_{t} \mu_{t-1}+\delta^{-} I_{t} \mu_{t-1}+\sum_{i=1}^{k} \lambda_{i} \Delta N E R_{t-i}+\sum_{i=1}^{k} \varphi_{i} \Delta O P_{t-i}+v_{t}, \\
& \triangle N E R_{t}=\alpha_{0}+\delta^{+} I_{t} \mu_{t-1}+\delta^{-} I_{t} \mu_{t-1}+\sum_{i=1}^{k} \lambda_{i} \Delta N E R_{t-i}+\sum_{i=1}^{k} \rho_{i} \Delta P O_{t-i}+v_{t}, \\
& \Delta N E R_{t}=\alpha_{0}+\delta^{+} I_{t} \mu_{t-1}+\delta^{-} I_{t} \mu_{t-1}+\sum_{i=1}^{k} \lambda_{i} \Delta N E R_{t-i}+\sum_{i=1}^{k} \omega_{i} \Delta R U B_{t-i}+v_{t}, \\
& \Delta N E R_{t}=\alpha_{0}+\delta^{+} I_{t} \mu_{t-1}+\delta^{-} I_{t} \mu_{t-1}+\sum_{i=1}^{k} \lambda_{i} \Delta N E R_{t-i}+\sum_{i=1}^{k} \omega_{i} \Delta N G_{t-i}+v_{t},
\end{aligned}
$$

where $\delta^{+}$and $\delta^{-}$denote the above and below speed of adjustment parameters for $N E R_{t}$ from its long-run equilibrium, respectively. $\alpha_{0}$ is the constant term. $\triangle O P_{t-i}, \Delta P O_{t-i}$, $\triangle R U B_{t-i}$, and $\Delta N G_{t-i}$ are the adjustment of oil, palm oil, rubber, and natural gas prices in the short run. $\varphi_{i}, \rho_{i}, \omega_{i}$, and $\vartheta_{i}$ are the coefficients on the lagged change terms. $v_{t}$ represents a white noise disturbance term.

Furthermore, the framework of Geweke (1982) and Hosoya (1991) comprises complex nonlinear functions of the parameters of the vector autoregression (VAR) model, which complicates the statistical inference for the feedback measures over time. Breitung and Candelon (2006) introduced a Granger causality test in the frequency domain that is easier to implement. The frequency domain or spectral analysis may be useful if causal links between variables change according to frequency, such as the short and long run. This study uses the spectral frequency domain approach to examine the causality between two series based on bivariate spectral density matrix of VAR among different frequencies. Breitung and Candelon (2006) proposed a simple approach to test the null hypothesis $\left(H_{0}\right)$. Null hypothesis $M_{y \rightarrow}$ ${ }_{x}(\omega)=0$ corresponds to $H_{0}: R(\omega) \beta=0 . \beta$ is the vector of the coefficients on the nominal exchange rate:

$$
R(\omega)=\left[\begin{array}{ccc}
\cos (\omega) & \cos (2 \omega) \ldots & \cos (p \omega) \\
\sin (\omega) & \sin (2 \omega) \ldots & \sin (p \omega)
\end{array}\right]
$$

In Eq. (15), the $F$-statistics are distributed as $F(2, T-2 p)$ for $\omega \in(0, \pi)$ and Fig. 2 presents several estimation restrictions, where symbol $T$ refers to the number of observations that measure the VAR model of order $p$. Furthermore, the frequency domain analysis allows observing nonlinearity and causality cycles for high or low frequencies. This study presents the relationship between energy and agriculture commodity prices and the nominal exchange rate in a VAR system. The bi-directional relationship between oil price and nominal exchange rate in the long and shortrun is expressed as per Eqs. (16) and (17); 


$$
\begin{aligned}
& O P_{t}=a_{1} O P_{t-1}+\ldots+a_{p} O P_{t-p}+b_{1} N E R_{t-1}+\ldots+b_{p} N E R_{t-p}+\varepsilon_{1 t}, \\
& N E R_{t}=a_{1} N E R_{t-1}+\ldots+a_{p} N E R_{t-p}+b_{1} O P_{t-1}+\ldots+b_{p} O P_{t-p}+\varepsilon_{2 t} .
\end{aligned}
$$

The bi-directional relationship between palm oil price and nominal exchange rate in the long and short run is explained in Eqs. (18) and (19);

$$
\begin{aligned}
& P O_{t}=a_{1} P O_{t-1}+\ldots+a_{p} P O_{t-p}+b_{1} N E R_{t-1}+\ldots+b_{p} N E R_{t-p}+\varepsilon_{1 t}, \\
& N E R_{t}=a_{1} N E R_{t-1}+\ldots+a_{p} N E R_{t-p}+b_{1} P O_{t-1}+\ldots+b_{p} P O_{t-p}+\varepsilon_{2 t},
\end{aligned}
$$

Where, the bi-directional relationship between rubber price and the nominal exchange rate in the long and short run is formulated asper Eqs. (20) and (21);

$$
\begin{aligned}
& R U B_{t}=a_{1} R U B_{t-1}+\ldots+a_{p} R U B_{t-p}+b_{1} N E R_{t-1}+\ldots+b_{p} N E R_{t-p}+\varepsilon_{1 t}, \\
& N E R_{t}=a_{1} N E R_{t-1}+\ldots+a_{p} N E R_{t-p}+b_{1} R U B_{t-1}+\ldots+b_{p} R U B_{t-p}+\varepsilon_{2 t},
\end{aligned}
$$

where the bi-directional relationship between natural gas price and the nominal exchange rate in the long and short run is explained in Eqs. (22) and (23);

$$
\begin{aligned}
& N G_{t}=a_{1} N G_{t-1}+\ldots+a_{p} N G_{t-p}+b_{1} N E R_{t-1}+\ldots+b_{p} N E R_{t-p}+\varepsilon_{1 t} \\
& N E R_{t}=a_{1} N E R_{t-1}+\ldots+a_{p} N E R_{t-p}+b_{1} N G_{t-1}+\ldots+b_{p} N G_{t-p}+\varepsilon_{2 t} .
\end{aligned}
$$

\section{Results and discussion}

Table 2 presents the descriptive statistics of the data. The mean value of palm oil price is highest, followed by natural gas and rubber prices. The oil price and natural gas price show increased volatility. Table 3 presents the Brock et al. (1991) test, known as the BDS test, at the 5\% significance level. BDS statistics are useful for detecting serial dependence in a time series. All series have values greater than the $5 \%$ significance level. Thus, the null hypothesis of iid data is rejected for all series. The empirical results suggest that the time series are non-linearly dependent, which indicates they exhibit nonlinear and chaotic behaviors (Brock 2018).

Furthermore, we start our empirical analysis by the Zivot and Andrews (2002) and Perron (1990) unit root tests to verify the stationarity of variables. Table 4 confirms all variables have a unit root problem in the presence of structural breaks. After the first differencing, variables are found to be stationary. This indicates that variables are integrated of $I(1)$. The structural break appears around in 1997, which highlights the start of the Asian financial crisis (AFC). This crisis has reflected most of the emerging

Table 2 Descriptive statistics

\begin{tabular}{lllll}
\hline Variables & Mean & Standard Deviation & Minimum & Maximum \\
\hline NER & 1.231 & 0.156 & 0.896 & 1.502 \\
OP & 3.692 & 0.702 & 2.268 & 4.880 \\
PO & 7.515 & 0.387 & 6.553 & 8.214 \\
RUB & 6.197 & 0.526 & 5.275 & 7.363 \\
NG & 6.844 & 0.681 & 5.506 & 8.009 \\
\hline
\end{tabular}


Table 3 BDS test statistics

\begin{tabular}{|c|c|c|c|c|c|c|c|c|c|}
\hline \multirow[t]{2}{*}{ m } & \multicolumn{5}{|c|}{ Univariate } & \multicolumn{4}{|c|}{ Multivariate } \\
\hline & NER & OP & $\mathrm{PO}$ & RUB & NG & Model-1 & Model-2 & Model-3 & Model-4 \\
\hline 2 & 0.184 & 0.187 & 0.178 & 0.185 & 0.195 & 0.151 & 0.159 & 0.153 & 0.16 \\
\hline 3 & 0.309 & 0.318 & 0.299 & 0.313 & 0.331 & 0.256 & 0.266 & 0.256 & 0.268 \\
\hline 4 & 0.393 & 0.408 & 0.381 & 0.399 & 0.425 & 0.323 & 0.338 & 0.321 & 0.339 \\
\hline 5 & 0.447 & 0.468 & 0.433 & 0.457 & 0.489 & 0.364 & 0.385 & 0.361 & 0.383 \\
\hline 6 & 0.484 & 0.508 & 0.465 & 0.493 & 0.532 & 0.389 & 0.416 & 0.387 & 0.411 \\
\hline
\end{tabular}

markets in East and Southeast Asia countries in 1997. In the case of Malaysia, the impact of the crisis began in mid-1997 when the ringgit had declined by $35.1 \%$ against the US currency (BNM 1997).

Subsequently, we observe the possibilities of a long-run relationship between the exchange rate and energy and agriculture commodity prices in Malaysia using the Engle-Granger cointegration. Table 5 presents each model's residuals, showing that null hypothesis of no cointegration is rejected at the $5 \%$ significance level. This implies that each energy and agriculture commodity is cointegrated with the nominal exchange rate, implying a long-run relationship. According to the long-run regression results, an increase in commodity prices would strengthen the ringgit against US dollar. The results are in line with Chen (2002). Bashar and Kabir (2013) also found long-run relationship between the nominal exchange rate and commodity prices. An explanation for this relationship is that Malaysia is an export-oriented country; thus, higher energy and agricultural commodity prices would improve its current account balance position and thereby appreciate the ringgit against the US dollar.

Next, the Enders and Siklos (2001) test is employed to examine the nonlinear threshold cointegration. Table 6 exhibits the threshold effects and focuses on convergence, threshold cointegration, and adjustment in the long-run equilibrium following a deviation in oil, palm oil, rubber, and natural gas price estimation models with a time break. Based on the TAR estimation, the threshold value of each model is zero, which is deterministic in nature. The point estimates advocate the convergence of long-run equilibrium, suggesting that the convergence for positive divergence is faster than the negative divergence from the long-run equilibrium of all commodity price estimation models. Among all models, the F-joint value (6.968) of the oil price model is greater than the $10 \%$ critical value, which means we can reject the null hypothesis of no

Table 4 Unit root test results

\begin{tabular}{|c|c|c|c|c|c|c|c|c|}
\hline \multirow[t]{3}{*}{ Variable } & \multicolumn{3}{|l|}{$\mathrm{ZA}$} & \multicolumn{5}{|l|}{ Perron } \\
\hline & \multicolumn{2}{|l|}{ Levels } & \multirow{2}{*}{$\begin{array}{l}\text { First difference } \\
\text { Statistics }\end{array}$} & \multicolumn{3}{|l|}{ Levels } & \multicolumn{2}{|c|}{ First difference } \\
\hline & Statistics & Break Date & & Break Date & Statistics & Break Date & Statistics & Break Date \\
\hline NER & -3.065 & 1997 M11 & $-16.677^{*}$ & 1998 M02 & -2.872 & 1997 M08 & $-18.800^{*}$ & 1998 M01 \\
\hline $\mathrm{OP}$ & -4.057 & 2014 M05 & $-10.379^{*}$ & 2008 M07 & -4.167 & 2014 M05 & $-16.386^{*}$ & 2008 M10 \\
\hline $\mathrm{PO}$ & -3.995 & 2006 M07 & $-12.091^{*}$ & 2001 M03 & -3.989 & 2006 M06 & $-12.626^{*}$ & 2008 M10 \\
\hline RUB & -3.224 & 2003 M08 & $-10.011^{*}$ & 2011 M03 & -3.199 & 2003 M07 & $-10.266^{*}$ & 2008 M11 \\
\hline NG & -4.035 & 2014 M05 & $-10.248^{*}$ & 2012 M08 & -4.035 & 2014 M05 & $-16.092^{*}$ & 2009 M04 \\
\hline
\end{tabular}

Note ${ }^{*}$ and ${ }^{*}$ represent $1 \%$ and $5 \%$ significance level 
Table 5 Engle-Granger cointegration estimates

\begin{tabular}{llllr}
\hline Test-statistics & Model-1 & Model-2 & Model-3 & Model-4 \\
\hline$Z(\mathrm{t})$ & $-2.284^{*}$ & $-2.244^{*}$ & $-2.263^{*}$ & $-2.201^{*}$ \\
\hline Note: ${ }^{*},{ }^{* *},{ }^{* * *}$ represents $1 \%, 5 \%$, and $10 \%$ significance level. Critical value at 1,5 and $10 \%$ level are equals to $-2.573,-$ \\
1.942 and -1.616 level, respectively
\end{tabular}

cointegration. This suggests the long-run relationship between oil price and the nominal exchange rate holds in Malaysia. Additionally, the null hypothesis of symmetric adjustment is tested between the nominal exchange rate and palm oil price by using the $F$-equal test. The $F$-equal value (1.618) rejects the null hypothesis of symmetry adjustment and confirms the cointegration adjustment is asymmetric in nature. In reality, the threshold value is non-zero and therefore Chan (1993) method's is applied to search for the threshold value for a consistent M-TAR.

Table 6 also presents the result of the consistent M-TAR model. The estimated threshold value by Chan (1993) is 0.016 for oil price, 0.007 for palm oil, 0.017 for rubber, and 0.015 for natural gas price models. The value suggests convergence in the M-TVECM estimates. The speed of adjustment is faster for a positive deviation than for negative one from the threshold value for all models. The null hypothesis of no cointegration is rejected in all models as the value of F-joint statistics is greater than the $10 \%$ critical value. This implies that all models show long-run cointegration between commodity prices and the nominal exchange rate. The inconsistency of the cointegration results warrants an examination of the possibility for asymmetry adjustment. The null hypotheses of $F$-equal symmetric adjustment for all models are rejected by the $10 \%$ critical value, hence indicating that the exchange rate and each commodity price model is strongly cointegrated under the asymmetric adjustment mechanism. Additionally, the findings are supported by the portfolio-balance model, which shows the relationship between commodity prices and the nominal exchange rate through the balance channel based on PPP. In Malaysia, increases in commodity prices influence the current account surplus, which in turn causes the appreciation of the currency. Ibrahim and Chancharoenchai (2014) and Alia et al. (2015) found a long-run relationship between oil price and the exchange rate using asymmetric cointegration. Recently, Churchill et al. (2019) and Narayan et al. (2019) found support for the nonlinear behavior of the relationship between the exchange rate and oil price.

As the last step of asymmetric cointegration adjustment, Table 7 reports the results of the adjustment of asymmetries for each commodity price on the nominal exchange rate. The results suggest that the speed of the adjustment of the positive deviation seems to be more rapid than the negative one for all models. Specifically, the adjustment of the positive deviation of oil price is significant at the $5 \%$ level, showing a negative relationship between oil price and the nominal exchange rate in the short run. This result implies that an increase in oil price leads to appreciating the currency. Additionally, the positive asymmetric adjustable parameter of palm oil price indicates the shortrun adjustment in the long run equilibrium, but only for a below threshold deviation, which is not statistically significant. The joint coefficient also shows the significant and negative impact of palm oil price on the exchange rate. This suggests that the positive deviation of palm oil price adjusted by the exchange rate improves the current account balance position. 


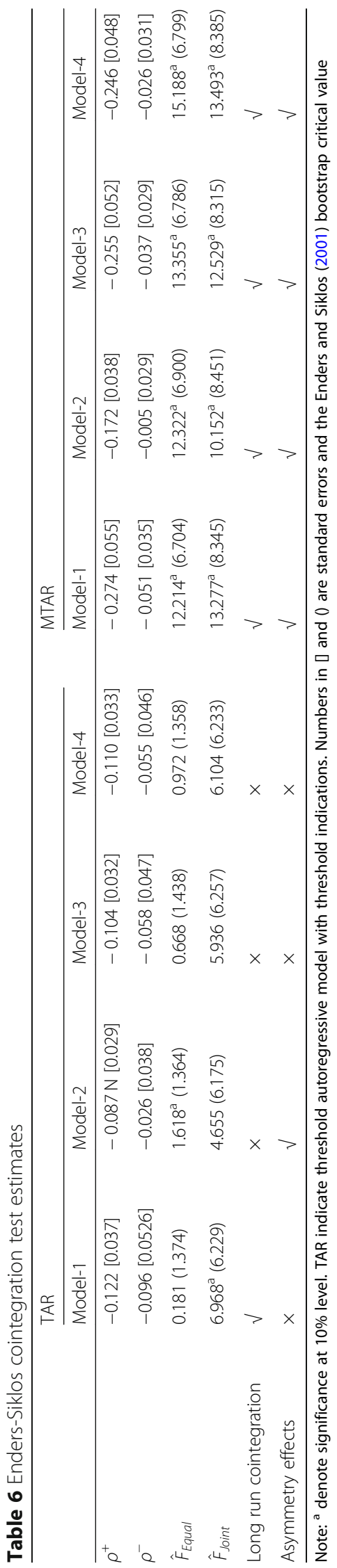


Table 7 The M-TVECM estimates

\begin{tabular}{|c|c|c|c|c|}
\hline & Model-1 & Model-2 & Model-3 & Model-4 \\
\hline$\triangle N E R_{t-3}$ & & $0.102^{* * *}(0.060)$ & $0.114^{* * *}(0.060)$ & $0.117^{* *}(0.059)$ \\
\hline$\triangle N E R_{t-5}$ & $0.168^{*}(0.059)$ & $0.212^{*}(0.058)$ & $0.187^{*}(0.058)$ & $0.222^{*}(0.059)$ \\
\hline$\Delta \mathrm{OP}_{\mathrm{t}}$ & $-0.037^{* *}(0.015)$ & & & \\
\hline$\Delta \mathrm{OP}_{\mathrm{t}-4}$ & $-0.030^{* * *}(0.015)$ & & & \\
\hline$\Delta \mathrm{PO}_{\mathrm{t}-1}$ & & $-0.045^{* *}(0.022)$ & & \\
\hline$\Delta \mathrm{PO}_{\mathrm{t}-4}$ & & $-0.037^{* * *}(0.021)$ & & \\
\hline$\Delta \mathrm{RUB}_{\mathrm{t}-5}$ & & & $-0.024(0.020)$ & \\
\hline$\Delta N G_{t-3}$ & & & & $-0.063^{*}(0.021)$ \\
\hline Break effect & $0.013(0.025)$ & $0.008(0.026)$ & $0.001(0.030)$ & $0.002(0.025)$ \\
\hline$\delta^{+}$ & $-0.033^{* *}(0.014)$ & $-0.036^{*}(0.013)$ & $-0.037^{*}(0.014)$ & $-0.038^{*}(0.014)$ \\
\hline$\delta^{-}$ & $-0.008(0.013)$ & $-0.009(0.014)$ & $-0.009(0.014)$ & $-0.011(0.015)$ \\
\hline \multicolumn{5}{|c|}{ Diagnostic tests } \\
\hline CUSUM & Stable & Stable & Stable & Stable \\
\hline$x_{\text {Serial }}^{2}$ & $2.663[0.264]$ & $3.255[0.196]$ & $2.534[0.282]$ & $2.309[0.315]$ \\
\hline R-square & 0.08 & 0.10 & 0.07 & 0.09 \\
\hline DW & 1.885 & 1.850 & 1.857 & 1.851 \\
\hline
\end{tabular}

Note: ${ }^{*},{ }^{*}$ and ${ }^{* * *}$ denote significance at 1,5 and $10 \%$ levels, respectively. Numbers in () and [] represent standard error and $p$-value, respectively

Moreover, the natural gas price also shows a significant negative impact on the nominal exchange rate. The empirical findings support that an increase in natural gas prices would depreciate the exchange rate and strengthen the ringgit. Further, the error correction term is correctly signed and adjusted for positive shocks in the short run. However, rubber price changes are likely to have no significant immediate impact on the nominal exchange rate. The results support the fact that the Malaysian economy obtains more benefits from the palm oil and energy sectors. Further, temporal breaks do not have any significant impact on the exchange rate evolution. This implies that the sample period does not support the impact on the Malaysian economy. The nominal exchange rate responds to an improvement in the current account balance. Additionally, the nominal exchange rate response to a positive adjustment is significant and larger than for a negative adjustment. The results are consistent with the findings of Chen et al. (2013) and Chen and Chen (2007). Additionally, Beckmann and Czudaj (2013) also discussed that wealth is transferred from oil importing to exporting countries, which indicates an improvement in the current account balance in domestic currency terms. Therefore, each model of energy and agriculture commodity price affect the nominal exchange rate through the wealth effect channel in the short run. As oil, palm oil, rubber, and natural gas are the main commodities in Malaysia, thus having a significant impact in the determination of nominal exchange rate in the long and short run. The relative importance of palm oil, natural gas, and oil prices indicate the role of commodity prices in the Malaysian economy.

The final empirical estimation explores the existence of spectral causality among variables over the long and short run. The test statistics lie in the interval $(0, \pi)$ for the $10 \%$ significance level. The frequencies correspond to a wavelength of $2 \pi / \sim 2$ years. Figure 5 presents the Granger causality of the nominal exchange rate and oil price in 


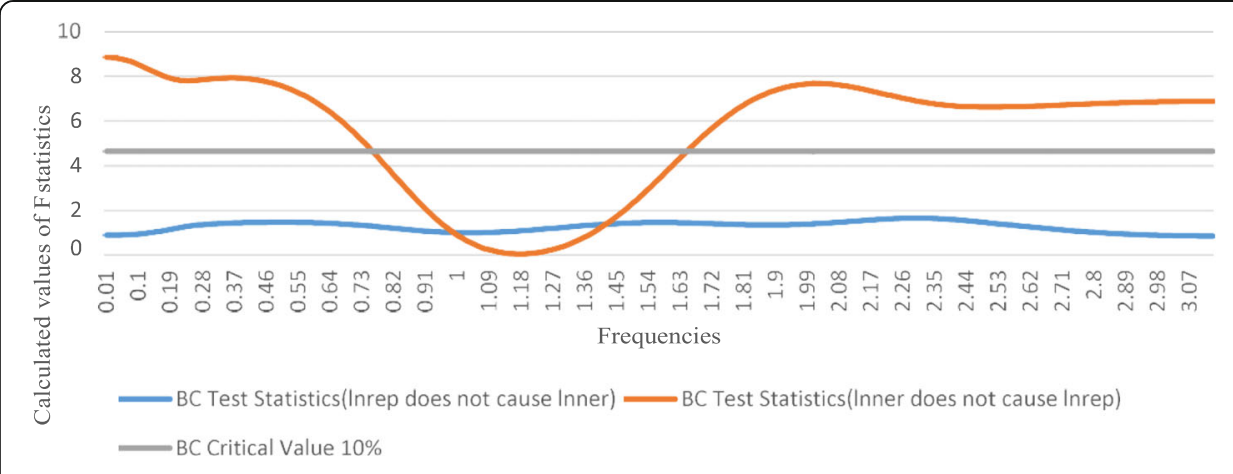

Fig. 5 The frequency domain causality between nominal exchange rate and oil price

the frequency domain, which is rejected at the $10 \%$ significance level. The nominal exchange rate cause oil price for frequencies for 8 to 9 months in the long run and corresponds to a wavelength of 3 to 4 months in the short run. A unidirectional causality runs from the nominal exchange rate to oil price in the long run. Theoretically, this result implies that Malaysia's base currency is thus USD, thus depending on the price strategy of the US currency. This result is supported by the denomination channel in that the US dollar appreciates when oil-exporting countries reinvest their earnings in USS denominated assets (Habib et al. 2016). The findings are in line with those of Tiwari et al. (2013) and Jain and Ghosh (2013), which investigate the Granger causality running from the exchange rate to oil prices. Tiwari et al. (2013) also confirm a unidirectional causality running from the exchange rate to oil price.

Figure 6 shows the influence of the business cycle on palm oil price and the nominal exchange rate. The palm oil price Granger influences nominal exchange rate in the long run. The null hypothesis is rejected at the $10 \%$ significance level for 4 to 5 months. The nominal exchange rate Granger causes palm oil price at low frequencies corresponding to 14 to 23 months in the long run and at a scale of 2.6 to 3.1 months in the short run. That is, palm oil price Granger causes nominal exchange rate in the long run, while the nominal exchange rate Granger causes palm oil price in the short run. The findings are supported by the wealth effect as transfer wealth channel. Ashfahany and Priyatna (2015) confirmed that palm oil price significantly affects the Indonesian and Malaysian currencies. Similarly, Aprina (2014) found that the increase in palm oil prices appreciates the Indonesian rupiah.

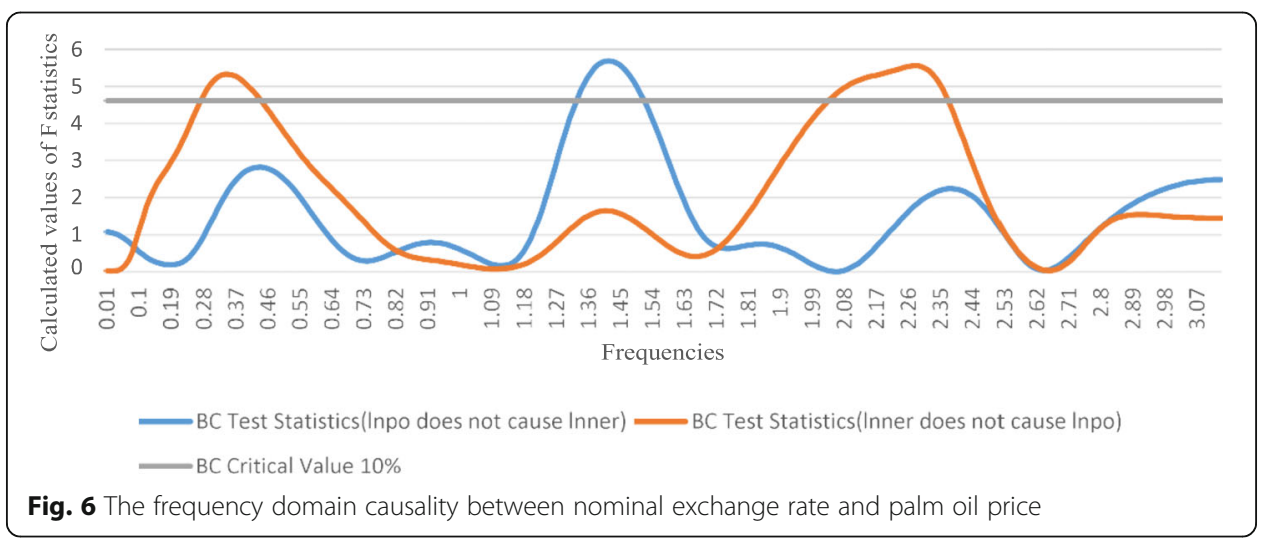




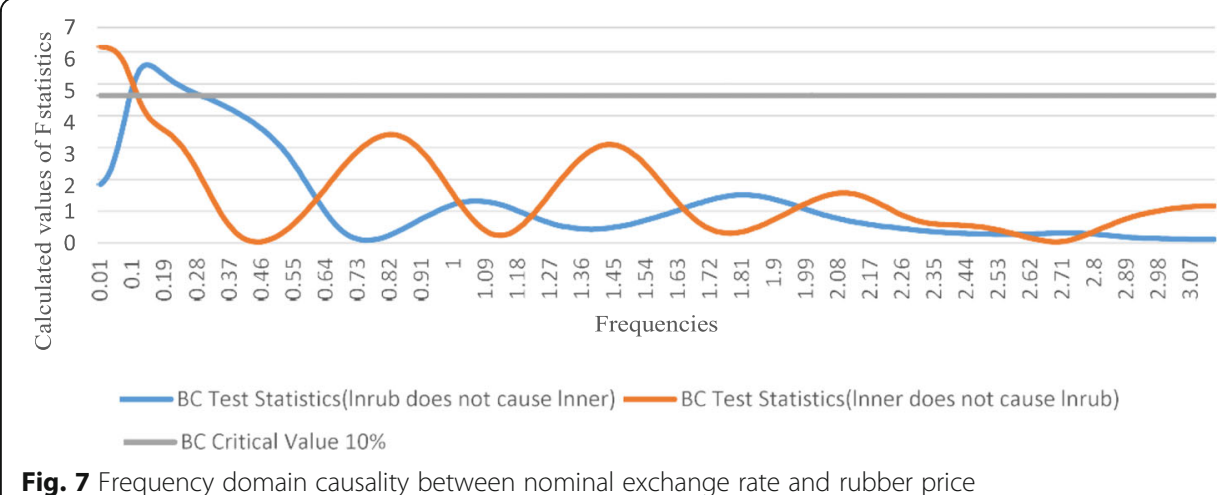

Figure 7 exhibits the results for rubber price and the nominal exchange rate. Rubber price Granger causes the nominal exchange rate at low frequencies in the long run, while the nominal exchange rate Granger causes rubber price at low frequency in the long run. This implies the existence of a long-run bidirectional causality between the nominal exchange rate and rubber price. The findings are supported the portfolio balance channel, based on PPP theory. The portfolio balance model treats domestic and foreign assets as imperfect substitutes. Hence, the exchange rate depends on the demand and supply for domestic and foreign assets. The theory supports the significant long-run cointegration relationship between the nominal exchange rate and rubber price in the export-oriented economy of Malaysia. However, previous studies provide limited evidence of the Granger causality between rubber price and the nominal exchange rate. For instance, Budiman and Fortucci (2003) and Burger et al. (2002) examine that exchange rate changes effect on natural rubber prices through portfolio balance channel in rubber trading countries.

Figure 8 displays the Granger causality between natural gas price and the nominal exchange rate in Malaysia. The findings indicate a bidirectional business cycle causality between the nominal exchange rate and natural gas price. That is, natural gas price Granger causes the nominal exchange rate for a wavelength of 3 to 10 months in the long and short run, while the nominal exchange rate Granger causes natural gas price for 3 to 57 months in the long and short run. The findings are supported by the wealth channel in that exporting countries lead to the appreciation of their domestic currency

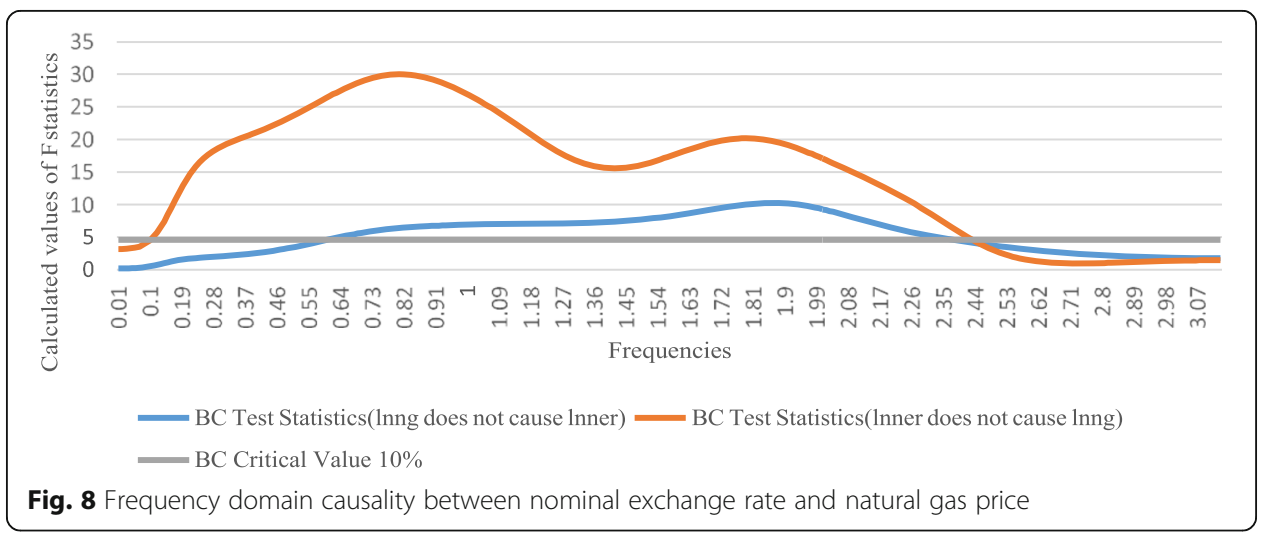


by increasing exports. The results clarify the Malaysian economy is a natural gas exporter, thus the wealth transfer positive shock on the currency account balance that appreciates the currency and improves the current account balance. Byambasuren (2013) and Kohlscheen et al. (2016) support the commodity impact on the nominal exchange rate.

\section{Conclusions}

This study examined the cointegration, asymmetric cointegration, and causal relationship between energy and agricultural commodity prices and the exchange rate in Malaysia from January 1994 to December 2017, allowing for asymmetric adjustments towards long-run equilibrium. The empirical results show the existence of a long-run relationship between the exchange rate and each commodity price by the Engle-Granger cointegration test. However, the Engle-Granger cointegration lacks a threshold adjustment in the long-run equilibrium position. As such, we utilized the TAR and MTAR models to determine the asymmetric response of the exchange rate to the level as well as changes in overvaluation of currency in Malaysia. These models are in favor of the threshold adjustment between variables, which further discloses asymmetries in the exchange rate adjustment process. However, the null hypotheses of cointegration and symmetric adjustment of all models were not rejected for the TAR model, but only for MTAR model with a non-zero threshold adjustment value. Therefore, the threshold error correction model is estimated using the MTAR specification. The findings explain that oil, palm oil, and natural gas prices influence the exchange rate in the short run. This suggests that the exchange rate responds to positive shocks by an appreciation of the currency. The threshold error term reflects that the speed of adjustment is faster for stabilizing the exchange rate. The TAR and MTAR models provide support for energy and agriculture commodity prices with long-run asymmetric adjustment.

Additionally, the findings explain the relationship between the exchange rate and each commodity price using frequency domain causality in the long and short run. The empirical findings show bidirectional Granger causality exist between the exchange rate and commodity prices in the long run. However, a unidirectional causality runs from the exchange rate to oil price in the long run. Malaysia is a net exporter of oil whose main currency is the USD. The findings support that the supply of oil is adjusted by the Malaysian government as a response to exchange rate changes and the price strategy of the US currency. Natural gas price influences the exchange rate in the short run, which suggests that currency appreciation could decline as the natural gas price rises. Therefore, when natural gas price increases, the government needs to weigh rapidly in the foreign exchange market to reduce exchange rate volatility.

Since Malaysia is an economy driven by commodity-based exports, rising commodity prices led to the accumulation of foreign exchange reserves which exert pressure on currency demand. As the demand for a currency increases, it causes the appreciation of the domestic currency. The findings show that the nominal exchange rate responds to positive shocks rather than negative ones. This implies that the exchange rate in Malaysia rather responds to overvaluation than the undervaluation. This also holds for the Asian financial crisis, when misalignment due to overvaluation was apparent. AN 
overvalued currency can result in unsustainable current account deficits, rising external debt, and the risk of speculative attacks at unfavorable cost. However, an undervalued currency has an equivocal effect on growth.

Regarding policy implications, its Malaysian policy makers should focus on monetary policy output whenever dealing with an overvaluation of the exchange rate. This output component supports the wealth effects channel, allowing to improve the current account balance that in turn stabilizes the exchange rate. Considering the wealth effects, policymakers prefer to boost the exports of domestic goods. The policy may be subject to higher undervaluation than overvaluation, resulting in boosted exports, reduced trade deficits, and lower the debt burdens. As such, this study could be expanded to include the role of macroeconomic news in commodity prices. Past studies have found that energy price, specifically that of oil, responds promptly to macroeconomic news. The identification of such effects could be an additional interesting avenue for future research.

Acknowledgements

Not applicable.

\section{Authors' contributions}

The first author contributed by handling the literature write-up and conducting data analysis. The second and third authors are the supervising committee contributed to guide throughout the manuscript preparation and the last author deal with data collection and data screening process. The authors read and approved the final version of the manuscript.

\section{Funding}

Not applicable.

\section{Availability of data and materials}

Data used in this paper were collected from the Department of Statistics, Central Bank of Malaysia and Organization of the Petroleum Exporting Countries (OPEC).

\section{Competing interests}

I confirm that I have read Springer Open's guidance on competing interests and have included a statement indicating that none of the authors have any competing interests in the manuscript. The authors of this manuscript are the Postgraduate Doctoral (PhD) candidates from Universiti Teknologi Malaysia (UTM) and their thesis supervisors. Since this study used secondary data from the official source of Malaysia's Department of Statistics, we therefore decide to not share the data to the public.

Received: 16 July 2019 Accepted: 12 March 2020

Published online: 16 April 2020

\section{References}

Alia H, Mukhtarb U, Tijanib B, Auwal M (2015) Dynamic relationship of exchange rates and crude oil prices in South Africa: are there asymmetries. Res J Finance Account 6(6):195-200

Alom F (2016) A note on the asymmetry and persistency of shocks in Malaysian exchange rate volatility. Malays J Econ Stud 53(2):227-238

Aprina H (2014) The impact of crude palm oil price on rupiah's rate. Bull Monetary Econ Banking 16(4):295-314

Ashfahany AE, Priyatna MF (2015) Analysis of world crude palm oil prices on the real exchange rate: a case study of Indonesia and Malaysia. International Conference on Trends in Business and Economics (ICTBE'15), London

Aziz MIA, Dahalan J, Hakim L (2013) Oil price and exchange rate relationship for ASEAN-5 countries: a panel study approach. World Appl Sci J 28(13):27-31

Bahmani-Oskooee M, Kutan AM, Zhou S (2008) Do real exchange rates follow a nonlinear mean reverting process in developing countries? South Econ J 74(4):1049-1062

Bashar O, Kabir SH (2013) Relationship between commodity prices and exchange rate in light of global financial crisis: evidence from Australia. Int J Trade Econ Financ 4(5):265-269

Basher SA, Haug AA, Sadorsky P (2016) The impact of oil shocks on exchange rates: a Markov-switching approach. Energy Econ 54:11-23

Beckmann J, Czudaj R (2013) Oil prices and effective dollar exchange rates. Int Rev Econ Finance 27(1):621-636

Beckmann J, Czudaj R (2017) Exchange rate expectations since the financial crisis: performance evaluation and the role of monetary policy and safe haven. J Int Money Financ 74:283-300

Benhmad F (2012) Modeling nonlinear Granger causality between the oil price and US dollar: a wavelet based approach. Econ Model 29(4):1505-1514

BNM (1997) Bank Negara Malaysia annual report 1997 Available at www.bnm.gov.my/ 
BNM (2018) Economic and financial developments in the Malaysian economy in the third quarter of 2018 Available at: http:// www.bnm.gov.my/

Breitung J, Candelon B (2006) Testing for short-and long-run causality: a frequency-domain approach. J Econ 132(2):363-378

Brock WA (2018) Nonlinearity and complex dynamics in economics and finance. The economy as an evolving complex system. CRC Press, Boca Raton, pp 77-97

Brock WE (1991) Nonlinear dynamics, chaos, and instability: statistical theory and economic 541 evidence. MIT Press. Cambridge

Budiman AF, Fortucci P (2003) Consultation on agricultural commodity price problems. Commodities and Trade Division $\mathrm{FAO}$, Rome

Burger K, Smit H, Vogelvang B (2002) Exchange rates and natural rubber prices, the effect of the Asian crisis. The 10th EAAE congress exploring diversity in the European Agri-food system, Zaragoza

Byambasuren TA (2013) A long-run relationship between real exchange rates and real commodity prices: the case of Mongolia. J Econ Bus Manage 1(3):257-261

Chan KS (1993) Consistency and limiting distribution of the least squares estimator of a threshold autoregressive model. Ann Stat 21(1):520-533

Chao X, Kou G, Peng Y, Alsaadi FE (2019) Behavior monitoring methods for trade-based money laundering integrating macro and micro prudential regulation: a case from China. Technol Econ Dev Econ 25(6):1081-1096

Chen JE, Lee CY, Goh LT (2013) Exchange rate and oil price: asymmetric adjustment. Appl Econ Lett 20(10):987-990

Chen SS (2004) Real exchange rate fluctuations and monetary shocks: a revisit. Int J Financ Econ 9(1):25-32

Chen SS, Chen HC (2007) Oil prices and real exchange rates. Energy Econ 29(3):390-404

Chen YC (2002) Exchange rates and fundamentals: evidence from commodity economies. Harvard University, Cambridge

Chen YC, Rogoff K (2003) Commodity currencies. J Int Econ 60(1):133-160

Chen YC, Rogoff KS, Rossi B (2010) Can exchange rates forecast commodity prices? The. Q J Econ 125(3):1145-1194

Chenery HB (1975) The structuralist approach to development policy. Am Econ Rev 65(2):310-316

Churchill SA, Inekwe J, Ivanovski K, Smyth R (2019) Dynamics of oil price, precious metal prices and the exchange rate in the long-run. Energy Econ 84. https://doi.org/10.1016/j.eneco.2019.104508

DOSM (2018) Malaysia economic performance third quarter 2018 Available at: https://www.dosm.gov.my/

EIA (2016) U.S. Energy Information Administration. Independent statistics analysis Available at: https://www.eia.gov/

Enders W, Siklos PL (2001) Cointegration and threshold adjustment. J Bus Econ Stat 19(2):166-176

Engle RF, Granger CW (1987) Co-integration and error correction: representation, estimation, and testing. Econometrica 55(2): $251-276$

Ferraro D, Rogoff K, Rossi B (2015) Can oil prices forecast exchange rates? An empirical analysis of the relationship between commodity prices and exchange rates. J Int Money Financ 54:116-141

Geweke J (1982) Measurement of linear dependence and feedback between multiple time series. J Am Stat Assoc 77(378): 304-313

Ghosh S (2011) Examining crude oil price-exchange rate nexus for India during the period of extreme oil price volatility. Appl Energy 88(5):1886-1889

Golub SS (1983) Oil prices and exchange rates. Econ J 93(371):576-593

Habib MM, Bütze S, Stracca L (2016) Global exchange rate configurations: do oil shocks matter? IMF Econ Rev 64(3):443-470

Hansen BE (2011) Threshold autoregression in economics. Stat Interface 4(2):123-127

Hartley PR, Medlock KB III (2014) The relationship between crude oil and natural gas prices: the role of the exchange rate. Energy J 35(2):25-44

Hosoya Y (1991) The decomposition and measurement of the interdependency between second-order stationary processes. Probab Theory Relat Fields 88(4):429-444

Hussain M, Zebende GF, Bashir U, Donghong D (2017) Oil price and exchange rate co-movements in Asian countries: detrended cross-correlation approach. Physica A 465:338-346

Ibrahim MH, Chancharoenchai K (2014) How inflationary are oil price hikes? A disaggregated look at Thailand using symmetric and asymmetric cointegration models. J Asia Pac Econ 19(3):409-422

IGU (2016) The world depends on natural gas. World LNG report Available at: http:/www.igu.org/publications

Jain A, Ghosh S (2013) Dynamics of global oil prices, exchange rate and precious metal prices in India. Resources Policy 38(1):88-93

Khan MK, Teng JZ, Khan MI (2019) Cointegration between macroeconomic factors and the exchange rate USD/CNY. Financial Innov 5(1):5. https://doi.org/10.1186/s40854-018-0117-x

Khashei M, Bijari M, Ardali GA (2009) Improvement of auto-regressive integrated moving average models using fuzzy logic and artificial neural networks (ANNs). Neurocomputing 72(4-6):956-967

Kohlscheen E, Avalos FH, Schrimpf A (2016) When the walk is not random: commodity prices and exchange rates. Int J Cent Bank 13(2):121-158

Krugman P (1983) Oil shocks and exchange rate dynamics. In: Exchange rates and international macroeconomics. University of Chicago Press, Chicago, pp 259-284

LeBaron B (1997) A fast algorithm for the BDS statistic. Stud Nonlinear Dynamics Econom 2(2):53-59

Lye CT, Chan TH, Hooy CW (2011) Nonlinear prediction of Malaysian exchange rate with monetary fundamentals. Econ Bull 31(3):1960-1967

Meese RA, Rogoff K (1983) Empirical exchange rate models of the seventies: do they fit out of sample? J Int Econ 14(1-2):3-24

MPOB (2019) Malaysian palm oil industry. Malaysian palm oil industry Available at: http://www.mpoc.org.my/

Narayan SW, Falianty T, Tobing L (2019) The influence of oil prices on Indonesia's exchange rate. Buletin Ekonomi Moneter dan Perbankan 21(3):303-322

Nazlioglu S, Soytas U (2012) Oil price, agricultural commodity prices, and the dollar: a panel cointegration and causality analysis. Energy Econ 34(4):1098-1104

Oladipo S, Akinbobola TO (2011) Budget deficit and inflation in Nigeria: a causal relationship. J Emerg Trends Econ Manag Sci 2(1):1-8

OPEC (2018) Organization of the Petroleum Exporting Countries: monthly oil market reports Available at: https:/www.opec.org/opec

Perron P (1989) The great crash, the oil price shock, and the unit root hypothesis. Econometrica 57(6):1361-1401 
Perron P (1990) Testing for a unit root in a time series with a changing mean. J Bus Econ Stat 8(2):153-62.

Reboredo JC, Rivera-Castro MA, Zebende GF (2014) Oil and US dollar exchange rate dependence: a detrended crosscorrelation approach. Energy Econ 42:132-139

Rossi B (2013) Exchange rate predictability. J Econ Lit 51(4):1063-1119

Tawadros GB (2017) Revisiting the exchange rate disconnect puzzle. Appl Econ 49(36):3645-3668

Teräsvirta T, Tjøstheim D, Granger CW (2010) Modelling nonlinear economic time series. Oxford University Press, Oxford

Tiwari AK, Albulescu CT (2016) Oil price and exchange rate in India: fresh evidence from continuous wavelet approach and asymmetric, multi-horizon Granger-causality tests. Appl Energy 179:272-283

Tiwari AK, Dar B, Bhanja N (2013) Oil price and exchange rates: a wavelet based analysis for India. Econ Model 31(1):414-422

Xie Z, Chen SW (2019) Exchange rates and fundamentals: a bootstrap panel data analysis. Econ Model 78:209-224

Yousefi A, Wirjanto TS (2004) The empirical role of the exchange rate on the crude-oil price formation. Energy Econ 26(5): 783-99.

Zivot E, Andrews DWK (2002) Further evidence on the great crash, the oil-price shock, and the unit-root hypothesis. J Bus Econ Stat 20(1):25-44

Zou L, Zheng B, Li X (2017) The commodity price and exchange rate dynamics. Theoretical Econ Lett 7:1770-1793

\section{Publisher's Note}

Springer Nature remains neutral with regard to jurisdictional claims in published maps and institutional affiliations.

Submit your manuscript to a SpringerOpen ${ }^{0}$ journal and benefit from:

- Convenient online submission

- Rigorous peer review

- Open access: articles freely available online

High visibility within the field

- Retaining the copyright to your article

Submit your next manuscript at $\boldsymbol{\nabla}$ springeropen.com 